AN OWNERSHIP THEORY OF THE TRADE UNION 



\title{
An Ownership
}

Theory of the

Trade Union

\section{Donald L. Martin}

\author{
University of California Press \\ Berkeley Los Angeles London
}


Published with the cooperation of the

Hoover Institution on War, Revolution and Peace

University of California Press

Berkeley and Los Angeles, California

University of California Press, Ltd.

London, England

Copyright (C) 1980 by The Regents of the University of California

Library of Congress Cataloging in Publication Data

Martin, Donald L.

An ownership theory of the trade union.

Bibliography: p. 147

Includes index.

1. Trade-unions. 2. Property. 3. Labor economics.

I. Title.

HD6483.M34 331.88'01 80-13147

ISBN 0-520-03884-3

Printed in the United States of America 


\section{To the memory of my father George H. Martin and the promise of my children Sean and Rachel}


